\title{
PREVALENCE OF SPINE DEFORMITY AMONG 7-11 YEAR OLD CHILDREN
}

\author{
Jasna Petrovic ${ }^{1}$, Vladimir Puzovic 2 , Dusica Djordjevic ${ }^{2}$, Milos Obrenovic ${ }^{3}$, Veselin Medic ${ }^{3}$, Vladimir Jakovljevic ${ }^{2}$ \\ ${ }^{1}$ Health Center Valjevo, Valjevo, Serbia \\ ${ }^{2}$ Faculty of Medical Sciences, University of Kragujevac, Kragujevac, Serbia \\ ${ }^{3}$ Center for Health, Exercise and Sport Science, Belgrade, Serbia
}

\section{PREVALENCA DEFORMITETA KIČME KOD DECE UZRASTA 7 - 11 GODINA}

\author{
Jasna Petrović1, Vladimir Puzović ${ }^{2}$, Dušica Đorđević2, Miloš Obrenović3, Veselin Medić3, Vladimir Jakovljević2 \\ IZdravstveni centar Valjevo, Valjevo \\ ${ }^{2}$ Fakultet medicinskih nauka, Univerzitet u Kragujevcu, Kragujevac \\ ${ }^{3}$ Centar za zdravlje, vežbanje i sportske nauke, Beograd
}

\begin{abstract}
Objective. The spine has a number of important roles in the human body. The curves of the spine are often used to characterize the posture. The aim of this study was to estimate the prevalence of the spine deformities among the youngest school-age children, as well as to find differences in the prevalence of those disorders among children of different gender, age and nutritional status.
\end{abstract}

Methods. Two doctors, specialists of orthopedics, inspected spine posture of 229 children from Belgrade elementary schools, in order to assess the prevalence of kyphosis, scoliosis, lumbar hyperlordosis and torticollis. Binary logistic regression was used to assess the influence of gender, age and nutritional status on the existence of deformities.

Results. The study included a total of 229 subjects (mean height of $138.4 \pm 9.6 \mathrm{~cm}$, weight $33.9 \pm 8.5 \mathrm{~kg}$, body mass index $17.5 \pm 2.6 \mathrm{~kg} / \mathrm{m}^{2}$ ). Prevalence of different types of spine deformities in examined population was: without deformities $76.9 \%(n=176)$ and with deformities $23.1 \%(n=53)$. The prevalence of different types of spinal deformities was as following: torticollis $0.4 \%(n=1)$, kyphosis $10.5 \%(n=24)$, scoliosis $5.2 \%(n=12)$, hyperlordosis $9.2 \%(n=21)$. The age, sex and body mass index did not have a significant influence on prevalence of this deformity.

Conclusion. Regular yearly school medical examination should be enough for detection of spine deformities at their onsets. The cooperation between physicians and physical education teachers must be enhanced and classes of physical education should be more oriented towards prevention and treatment of postural deformities of the youngest.

Key words: child; spinal curvatures; kyphosis; lordosis; scoliosis; prevalence; risk factors.

\section{INTRODUCTION}

The spine has a number of important roles in the human body. Besides the role in the protection of the internal organs in pelvis and thorax and the fact that the spinal cord which carries impulses to all parts of the body passes through it, it has vital roles in the human

\section{SAŽETAK}

Cilj. Kičma ima bitnu ulogu u čovekovom organizmu. Njene krivine najčešće se koriste da okarakterišu posturu. Cilj ove studije bio je da se proceni prevalenca deformiteta kičme kod najmlađe školske dece, kao i da se ukaže na razlike u prevalenci kičmenih deformiteta kod dece različitog pola, uzrasta i stepena uhranjenosti.

Metode. Na uzorku od 229 ispitanika, metodom inspekcije, dva lekara specijalista ortopedije procenila su rasprostranjenost deformiteta kifoze, skolioze, lumbalne hiperlordoze i tortikolisa, među decom beogradskih osnovnih škola. Koristili smo binarne logističke regresije da bismo pokazali uticaj pola, starosti $i$ uhranjenosti na postojanje deformiteta.

Rezultati. Studija je obuhvatila ukupno 229 dece (srednja vrednost visine 138,4 $\pm 9,6 \mathrm{~cm}$, težine $33,9 \pm 8,5 \mathrm{~kg}$, indeksa telesne mase $17,5 \pm 2,6 \mathrm{~kg} / \mathrm{m} 2$ ). Prevalencija razlicitih vrsta deformiteta kičme $u$ ispitivanoj populaciji bila je: bez deformiteta $76,9 \%(n=176)$ i sa deformitetima $23,1 \%(n=$ 53). Prevalencija različitih vrsta deformiteta kičmenog stuba bila je sledeća: tortikolis 0,4\% $(n=1)$, kifoza 10,5\% $(n=$ 24), skolioza 5,2\% $(n=12)$, hiperlordosis 9,2\% $(n=21)$. Zaključeno je da pol, uzrast i uhranjenost ne utiču značajno na prevalencu ovog deformiteta.

Zaključak. Redovna kontrola posturalnog statusa kičme, koja se sprovodi jednom godišnje, dovoljna je da se utvrdi eventualno postojanje deformiteta $u$ početnom stadijumu.Saradnja lekara i nastavnika fizičkog vaspitanja mora da se poboljša, a časovi fizičkog vaspitanja moraju se više orijentisati na prevenciju $i$ tretman posturalnih deformiteta najmlađih.

Ključne reči: dete; krivine kičme; kifoza; lordoza; skolioza; prevalenca; faktori rizika.

kinesiology. It represents a vertical axis and a pillar of stability of the body which enables maintenance of an upright posture. It is also an extremely important part of kinetic chains in the human body in motion. So the correct spine posture has a very important role in the motor ability, quality of life and aesthetics of a human being (1-3). 
The curves of the spine are often used to characterize the posture $(4,5)$. In the normal spine there are four types of spinal curvatures important for balance, flexibility, and stress absorption and distribution. Those are cervical lordosis, thoracic kyphosis, lumbar lordosis and sacral kyphosis. Kyphosis and lordosis are terms that describe the shape of the spine in the sagittal plane: kyphosis is concave anteriorly and convex posteriorly while lordosis is vice versa. Physiologically, the thoracic kyphosis is 20 $45^{\circ}$. A curvature greater than $45^{\circ}$ indicates hyperkyphosis, while the appearance of kyphosis in the cervical or lumbar region indicates a pathological kyphosis (6). Primary lordosis is rarely encountered; it is often seen as secondary lordosis - compensatory strain due to kyphosis or as an integral part of an idiopathic scoliosis (6), the third most common deformity of the spine that occurs in the frontal plane - partial or full lateral bending of the spine (7).

Children in juvenile age are often diagnosed with scoliosis, kyphosis and lumbar lordosis, or any combination of them. Besides idiopathic deformities, whose causes are still not the clearest, a big percentage of spine deformities are caused by the modern way of life, i.e. malnutrition, inactivity and obesity (8). In addition to this, inadequate school desks and too heavy school bags are two additional factors that negatively influence the spine curvature (8-11). The above-mentioned characteristics of modern life have an especially negative impact on the young organism. Weak musculature and bad posture cause functional deformities and over time those deformities become structural and irreversible, which causes many problems in adulthood. Early detection of deformities is of great importance in prevention of progression of existing deformities and their treatment.

The aim of this study was to estimate the prevalence of the spine deformities among the youngest school-age children, as well as finding differences in the prevalence of those disorders among children of different gender, age and nutritional status.

\section{PATIENTS AND METHODS}

Data on the presence of spine deformities among 7-11 year old pupils were recorded during the regular school medical examination. The study included a total of 229 respondents, of which 126 were boys and 103 were girls. Measurements were performed at the Center for Health, Exercise and Sport Sciences in Belgrade, by two physicians, specialists in orthopedics. Measurement of height was performed using the Martin's anthropometer (12), while weight measurement was performed by digital bioelectrical impedance using the Soehnle Classic Palma Digital Bathroom Scales 62871. Respondents were divided into categories of nutritional status based on body mass index (BMI), taking into account their age (13). The status of the spine was determined by visual assessment method from front, side and rear side of the body (14). The deviation from the normal status of spinal posture was reflected in the leaning posture of the head to one side, asymmetry of the chest, increasing the normal physiological spinal curves, asymmetric position of the shoulder and shoulder blades, Lorentz triangle imparity and asymmetry of the pelvic bone position.

Statistical analysis was performed by using the statistical package SPSS 10. For a description of the parameters of interest we used the methods of descriptive statistics: measures of central tendency (mean value), measures of variability (standard deviation), percentages and tabulation. The dependence of the frequency of spine deformity on sex, age and nutritional status was assessed by chi square test. For the influence of gender, age and nutritional status on existence of deformities we used binary logistic regression.

\section{RESULTS}

The study included a total of 229 subjects (mean height of $138.4 \pm 9.6 \mathrm{~cm}$, weight $33.9 \pm 8.5 \mathrm{~kg}$, body mass index $17.5 \pm 2.6 \mathrm{~kg} / \mathrm{m}^{2}$ ). The prevalence of different types of spine deformities in the examined population were: without deformities $76.9 \%(n=176)$ and with deformities $23.1 \%(n=53)$. The prevalence of different types of spinal deformities was as following: torticollis $0.4 \% \quad(n=1)$, kyphosis $10.5 \% \quad(n=24)$, scoliosis $5.2 \% \quad(n=12)$, hyperlordosis $9.2 \%(n=21)$. Some subjects had signs of more than one deformity, so the sum of the number of subjects with different types of spine deformities is greater than total number of subjects with spine deformities.

Table 1. Prevalence of spine deformities in groups defined by gender, age and BMI.

\begin{tabular}{|c|c|c|}
\hline Variable & $\begin{array}{c}\text { Without } \\
\text { deformities }\end{array}$ & $\begin{array}{c}\text { With } \\
\text { deformities }\end{array}$ \\
\hline \multicolumn{3}{|l|}{ Gender } \\
\hline Boys $(n=126)$ & $93(73.8 \%)$ & $33(26.2 \%)$ \\
\hline Girls $(n=103)$ & $83(80.6 \%)$ & $20(19.4 \%)$ \\
\hline \multicolumn{3}{|l|}{ Age } \\
\hline 7 years $(n=15)$ & $12(80 \%)$ & $3(20 \%)$ \\
\hline 8 years $(n=62)$ & $48(77.4 \%)$ & $14(22.6 \%)$ \\
\hline 9 years $(n=53)$ & $41(77.4 \%)$ & $12(22.6 \%)$ \\
\hline 10 years $(n=62)$ & $48(77.4)$ & $14(22.6)$ \\
\hline 11 years $(n=37)$ & $27(73 \%)$ & $10(27 \%)$ \\
\hline \multicolumn{3}{|l|}{ Body Mass Index } \\
\hline Underweight $(\mathrm{n}=6)$ & $4(66.7 \%)$ & $2(33.3 \%)$ \\
\hline Healthy $(n=173)$ & $130(75.1 \%)$ & $43(24.9 \%)$ \\
\hline Overweight $(\mathrm{n}=36)$ & $32(88.9 \%)$ & $4(11.1 \%)$ \\
\hline Obese $(n=14)$ & $10(71.4 \%)$ & $4(28.6 \%)$ \\
\hline
\end{tabular}




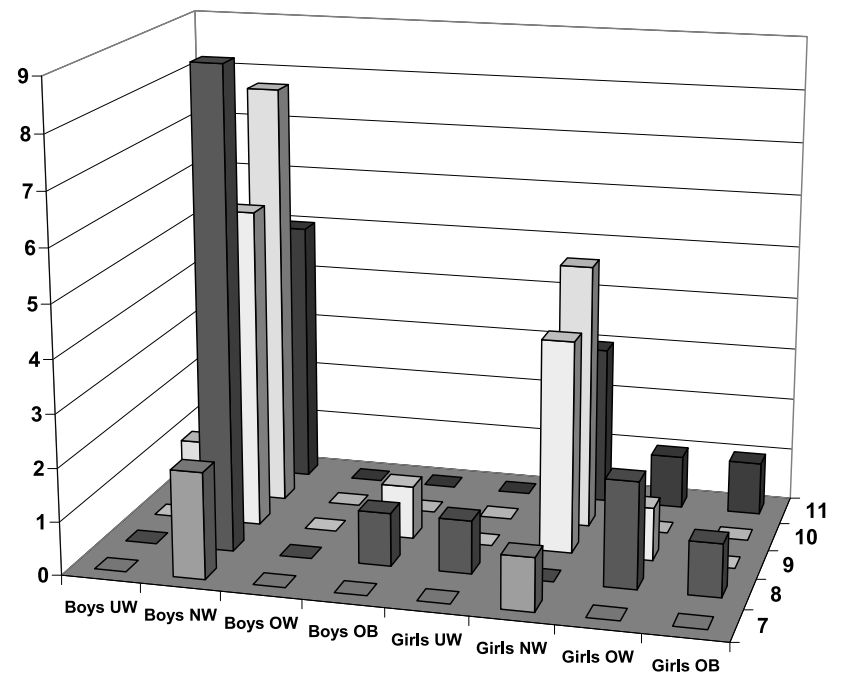

Figure 1. Prevalence of spine deformity depending on the combination of factors: sex, age and BMI (UWunderweight, $N W$-normal weight, $O W$-overweight, $O B$ obese).

Table 1 and figure 1 show the prevalence of spine deformity among the subjects depending on gender, age, BMI and combinations of these factors. It can be seen that, for example, prevalence of spine deformity is bigger in boys than in a girls. However, sex, age and BMI were not associated significantly with the existence of spine deformities, as assessed with logistic regression analysis (OR and $\mathrm{p}$ for sex, age and BMI were 0.692 and 0.255 , 1.088 and $0.524,0.794$ and 0.416 , respectively). The ChiSquare analysis also showed the independence of the prevalence of spine deformities from sex, age and BMI $\left(\operatorname{sex} \chi^{2}=1.106, \mathrm{df}=1, \mathrm{p}=0.293 ;\right.$ age $\chi^{2}=0.427, \mathrm{df}=4$, $\mathrm{p}=0.980$; BMI $\chi^{2}=3.797, \mathrm{df}=3, \mathrm{p}=0.284$ ). Therefore, our study excluded the significant association between the spinal curvature deformities and proposed risk factors which were the objective of our research.

\section{DISCUSSION}

The prevalence of the spine deformities in 7 to 11 year old children who were the subjects in our research was found to be $23.1 \%$. We found that the most common deformity in our study group was kyphosis, which occurred in $10.5 \%$ respondents. Other studies found different results. Some found high kyphosis prevalence, such as Bogdanovic (15) who reported kyphosis in $43.14 \%$ of 11 year old pupils, or Milenković et al. (16) who found it in $51.4 \%$ of children $7-10$ years old. On the other hand, among somewhat older pupils (11-14 years old) kyphosis prevalence of $4 \%$ was reported (17). The higher prevalence of kyphosis in younger respondents may be explained by the specificity of their growth period. Period between 7 and 11 years of age represents a delicate period that is suitable for the occurrence of kyphosis (18).
The exposure of the still weak children's body to long periods of sitting in the classroom causes a hunched position and consequently kyphotic posture. This relationship between bad spine posture and long forced positions was well described in a study by Popova et al. (8).

In this study scoliosis was found in 12 respondents, which represents $5.2 \%$ of all respondents. This is similar to results reported by Milenkovic et al. (17) who found scoliosis in $7.8 \%$ of $11-14$ year old pupils. On the other hand Ostojic et al. (19) explored the prevalence of scoliosis in 2517 primary school children (7-14 years old) and reported that $33.4 \%$ of examinees had spine deformities, from which $11.8 \%$ respondents were suspected structural scoliosis. Prevalence of spine deformities in that research was $28.3 \%$ in the pupils from the first grade, $28.9 \%$ in the third grade, $35.9 \%$ in the fifth and $28.9 \%$ in the seventh grade. Prognosis of scoliosis is worse when it occurs earlier. In puberty growth momentum induces a sudden deterioration of the deformation (6). So this deformity, because of potential progression and the health-aesthetic problems that it can cause, requires special attention during the treatment as well as regular medical monitoring.

Hyperlordosis in our study occurred in $9.2 \%$ of pupils. Lordosis usually develops as a compensatory curvature of kyphosis, and it is called secondary lordosis. Besides this, the most common causes of lordosis are weak abdominal muscles and the shortening of the psoas major muscle, which may be due to insufficient physical activity and passive lifestyle (18). So for a treatment of this deformity, the most important is correction of primary deformity (kyphosis) and proper muscle development.

Torticollis is the deformity that occurred only in one case, or $0.4 \%$ of pupils in our study. For the successful treatment of torticollis the most important factor is early diagnosis, immediately after birth. Early diagnosis and proper treatment approach allows great success to correct this deformity, which may explain its low prevalence among the tested pupils.

In conclusion, the results of our study showed that the prevalence of spine deformities in children 7 to 11 years old was not dependent on gender, age or body mass index of respondents, but that in this population the prevalence of incorrect posture was relatively high. It suggests the need for its prevention and treatment. Regular yearly school medical examination should be enough for detection of spine deformities in their beginning i.e. in functional stadium. Cooperation between physicians and physical education teachers must be enhanced and classes of physical education should be more oriented towards prevention and treatment of postural deformities of the youngest. 


\section{ABBREVIATIONS}

BMI - Body Mass Index

\section{REFERENCES}

1. Sugita K. Epidemiological study on idiopathic scoliosis in high school students. Prevalence and relation to physique, physical strength and motor ability. Jpn J Publ Health 2000; 47: 320-25.

2. Freidel K, Petermann F, Reichel D, Steiner A, Warschburger P, Weiss HR. Quality of life in women with idiopathic scoliosis. Spine 2002; 27: E87-E91.

3. Tones M, Moss N, Polly DW. A review of quality of life and psychosocial issues in scoliosis. Spine 2006; 31: 3027-38.

4. Adams MA, Dolan P, Marx C, Hutton WC. An electronic inclinometer technique for measuring lumbar curvature. Clin Biomech 1986; 1: 130-34.

5. Bridger RS, Wilkinson D, van Houweninge T. Hip joint mobility and spinal angles in standing and in different sitting postures. Hum Factors 1989; 31: 229-41.

6. Kovač V. Problematika kralješnice razvojne dobi. Paediatr Croat 2000; 44 (Supl 1): 199-204. (in Croatian)

7. Kocijancic RI. Higijena. Beograd: Zavod za udžbenike i nastavna sredstva, 2002. (in Serbian)

8. Ramova EP, Lazović M. Prevencija deformiteta kičme kod adolescenata zbog dugih prinudnih stavova. Med Pregl 2010; 63: 855-58.

9. Grimmer KA, Williams MT, Gill TK. The associations between adolescent head-on-neck posture, backpack weight, and anthropometric features. Spine (Phila Pa 1976) 1999; 24: 2262-7.

10. Korovessis P, Koureas G, Papazisis Z. Correlation between backpack weight and way of carrying, sagittal and frontal spinal curvatures, athletic activity, and dorsal and low back pain in schoolchildren and adolescents. J Spinal Disord Tech 2004; 17: 33-40.
11. Mackenzie WG, Sampath JS, Kruse RW, Sheir-Neiss GJ. Backpacks in children. Clin Orthop Relat Res 2003; 409: 78-84.

12. Eston R, Reilly T. Kinanthropometry and exercise physiology laboratory manual: tests, procedures and data. Volume One: Anthropometry. 3 ed. London, New York: Taylor \& Francis, 2009.

13. BMI Percentile Calculator for Child and Teen Metric Version. Atlanta: Centers for Disease Control and Prevention, 2012. (http://apps.nccd.cdc.gov/dnpabmi/ Calculator.aspx $?$ CalculatorType $=$ Metric)

14. Pineda S, Bago J, Gilperez C, Climent JM. Validity of the Walter Reed Visual Assessment Scale to measure subjective perception of spine deformity in patients with idiopathic scoliosis. Scoliosis 2006, 1: 18.

15. Bogdanović, Z. Manifestation of kyphotic and lordotic bad body posture influenced by backpack carrying type. In: Joksimović S, ed. Proceedings of "Fiscommunications 2005". Nis: Faculty of Physical Education, 2005: 59-65.

16. Milenković S, Živković D, Milijić S, Ignjatović I, Pavlović Z. Status of the postural deformities and body deformities in younger school age children in communities Zaječar, Kruševac and Čačak. In: Živković D, ed. Proceedings of "Fis-communications 2003". Nis: Faculty of Physical Education, 2003: 320-4.

17. Milenković SM, Kocijančić RI, Belojević GA. Left handedness and spine deformities in early adolescence. Eur J Epidemiol 2004; 19: 969-72.

18. Radisavljević M. Korektivna gimnastika sa osnovama kineziterapije. Beograd: Fakultet sporta i fizičkog vaspitanja, 2001. (in Serbian)

19. Ostojic Z, Kristo T, Ostojic L, et al. Prevalence of scoliosis in school-children from Mostar, Bosnia and Herzegovina. Coll Antropol 2006; 30: 59-64. 